\title{
EL DOCUMENTAL FUEGUINO CHILENO EN EL SIGLO XXI. UNA MIRADA DESDE LA ANTROPOLOGÍA VISUAL
}

FELIPE A. MATURANA D.*

\section{RESUMEN}

En los últimos años distintos realizadores audiovisuales han decido abordar la temática indígena fueguina, usando un lenguaje audiovisual evocativo y subjetivo, que rompe con las convenciones del documental expositivo que por mucho años perduró en la representación indígena audiovisual.

La presente investigación busca conocer y comprender las formas estructurales en que estos nuevos artefactos audiovisuales representan al indígena fueguino a través de un análisis fílmico en tres niveles: Plano General, Plano Medio y Primer Plano.

PALABRAS CLAVES: Documental, Indígenas Fueguinos, Análisis Estructural del Relato, Dispositivos, Procedimientos Visuales y Tierra del Fuego.

\section{FUEGUIAN DOCUMENTARY CHILEAN IN THE XXth CENTURY. A VISUAL ANTHROPOLOGY PERSPECTIVE.}

\begin{abstract}
In the past years different audiovisual produces have decided to engage the theme of Fueguian indigenous peoples using an audiovisual language that is evocative and subjective, and therefore departs from the conventional expository documentary characteristic of decades of audiovisual representation of indigenous peoples. The research described here in seeks to understand the structural forms in which these new audiovisual artifacts represent Fueguian indigenous peoples via a cinematic analysis at three levels: Long-shot, Medium-shot and Close Up.
\end{abstract}

KEY WORDS: Documentary, Fueguian indigenous peoples, structural analysis of narratives, visual tools and procedures, Tierra del Fuego.

* Co-investigador proyecto Fondecyt №1060681"La representación de las alteridades: fotografías de los indígenas del Norte G rande (1911-1990)". Las Lomas del Manzano 0438, San J osé de Maipo, Santiago, Chile. E-mail: avisual@ uchile.cl 


\section{PROBLEMATIZACIÓN}

Los trabajos de análisis cinematográfico son escasos en Chile, un primer antecedente lo constituye el trabajo de Alicia Vega quien distingue entre largometrajes argumentales y documentales. ${ }^{1}$ Los primeros corresponden principalmente a películas con puesta en escena o teatralización como «El Húsar de la Muerte», «El Chacal de Nahueltoro» y « ulio comienza en J ulio», mientras los segundos se caracterizan por ser registro directo de la realidad, como los primeros cinemáticos de principios del 1900 hasta las distintas producciones audiovisuales realizadas a partir de la creación del Instituto Fílmico (UC / 1955) y del Centro de Cine Experimental (U de Chile / 1957) de los cuales emergen figuras como Patricio Guzmán, Héctor Ríos y Carlos Flores. ${ }^{2}$

Sin embargo, cuando visualizamos películas que abordan la temática indígena el simple criterio de puesta en escena $\mathrm{v} / \mathrm{s}$ registro directo de la realidad no es suficiente. En el caso fueguino, un primer antecedente cinematográfico es la película del sacerdote salesiano Alberto María De Agostini, grabada entre 1910 y 1930 (Fig. 1a y 1b), en la cual encontramos actuaciones o «puestas en escena» de arqueros O nas disparando sus flechas a guanacos imaginarios, y registros espontáneos de canoeros Alacalufes con andrajosas ropas occidentales producto de un fuerte proceso de transculturación. ${ }^{3}$ En este sentido, la pelí-

1 Vega, Alicia et al. 1979. «Re-visión del cine chileno». Este trabajo fue realizado en conjunto con «los jóvenes cineastas Carlos Besa, Cristián Lorca, Gerardo Cáceres, Roberto Roth e Ignacio Agüero» (p.7).

2 En el largo listado de documentales presentado por los autores destacan los trabajos «Recuerdos del Mineral 'EI Teniente'» de Salvador Giambastiani (1957 [1915] / $35 \mathrm{~mm} / 12$ '), las actualidades de Andes Film a cargo de Gustavo Bussenius (discípulo de Giambastiani) que operó entre 1920 y 1930, las películas educativas de Armando Rojas Castro quién fue director del Instituto de Cinematografía Educativa (1930-1940) y fundador del Noticiero DIC que más tarde se transformó en EMELCO (1954), y un listado de realizadores independientes como j orge Infante Biggs «C ien años del carbón en Lota», Edmundo Urrutia «El corazón de una Nación» (1928), Guillermo Yánquez «Casa de Socorro de Puente Alto», Egidio Heiss «El terremoto de Chillán», Patricio Kaulen «Sewell, ciudad del cobre» (1955), Fernando Balmaceda «Energía Gris» (1960, Premio Círculo Críticos de Arte), Armando Parot «EI Hierro», y J orge di Lauro y Nieves Yankovic «Andacollo» (1958 / $16 \mathrm{~mm}$ ) entre muchos otros (Vega et. al. 1979:209).

3 Motsny 1950 cula de De Agostini comparte tanto aspectos argumentales (puesta en escena) como documentales (registro directo de la realidad). ${ }^{4}$

$E l$ «documental fueguino» chileno aparece tímidamente a fines del siglo $X X^{5}$ pero se consolida en el año 2000 , después de una verdadera revolución documental indígena ocurrida entre 1986 y $1994 .{ }^{6}$ La razón de esta ausencia del tema

4 Pese al incuestionable valor patrimonial de esta producción cinematográfica, no existen trabajos de archivo o históricos que nos permitan conocer con certeza el titulo, su duración y fecha de estreno de la obra De Agostini. En Chile hay archivos que señalan que la producción se titula «Zona austral» mientras otros indican «Tierras Magallánicas». Sin embargo, J uan Carlos Portas, autor de «Patagonia, cinefilia del extremo austral del mundo» (2001), señala que la obra del argentino Alberto Maria De Agostini tiene por título «Indios Onas y Yaganes», y que técnicamente es un cortometraje de secuencias (ni argumental, ni documental) estrenado entre 1928 y 1932. En cuanto a la duración, es comprensible encontrar distintas versiones del film, pues su fragilidad material (nitrato de celulosa) provocó la destrucción de algunas partes del film. En conversación con el padre Tico, re-fundador y guía del actual Museo Salesiano de la Misión La Candelaria (Río Grande, Argentina) quien conoció a De Agostini y su obra audiovisual, nos señaló que la película original del Padre De Agostini era mucho más extensa en su temática indígena (conversación personal, diciembre 2003).

5 En 1985 Luis Solar y J osé Pérez de Arce realizan el video «Selknam» (1985 / 30') a base de un diaporama que ilustra la forma de vida, mitos y ceremonias de este pueblo fueguino que tuvo una difusión discreta. En 1991 TVN (Pta. Arenas) en co-producción con el Fondecyt $\mathrm{n}$-900001 realizan el video histórico-arqueológico «El Valle del Secreto» realizado por Juan Ursic, Mauricio Massone y Carlos Vega (1991 / 33'), el cual tuvo una amplia difusión por la Red Austral de Televisión Nacional y por algunos canales de televisión argentina, causando cierto impacto en el medio patagónico durante los años 1991 y 1992. Sin embargo, su estructura narrativa del tipo expositiva/pedagógica, propio del mundo periodístico, lo alejan del tipo documental de autor analizado por el proyecto Fondecyt $n^{\circ} 1030029$ que enmarca esta investigación (ver Anexo 2). En 1992 el proyecto documental «Mankacen: el cazador de sombras», de Ivan Sanhueza Díaz, es financiado por FONDART (no se pudo conseguir copia para su visualización). Y en 1993 Sergio Lausic realiza «H omenaje a los hombres australes» (1993 / 23'), video de difusión de escaso impacto local.

6 Según nuestro catastro (Proyecto Fondecyt $\mathrm{n}$-1030029) en Chile hasta el 2003 existen 25 documentales indígenas, de los cuales 14 (más del 50\%) fueron realizados entre 1986 y 1994 (menos de 10 años). El año con más producciones audiovisuales indígenas es 1988 con cuatro producciones, tres del norte y una mapuche (ver listado de Documentales Indígenas Chilenos, Anexo 2). 


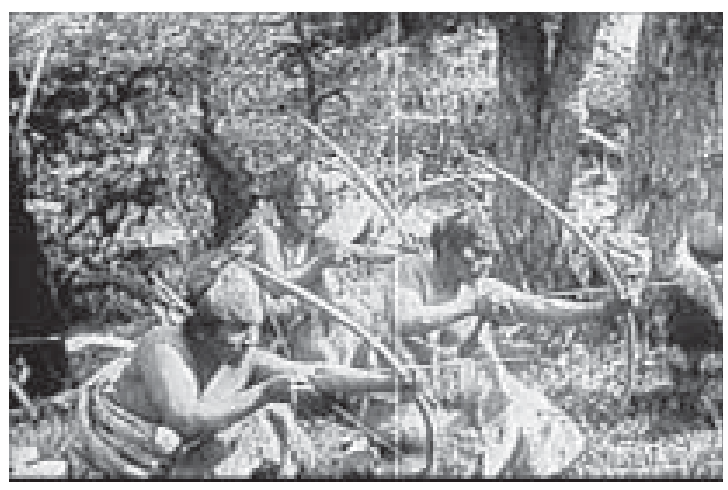

Fig. 1a. Fotograma de la película de Alberto M. De Agostini.

fueguino en el documental chileno se relaciona estrechamente con el fuerte proceso de mortandad sufrida por estas poblaciones indígenas a fines del siglo $X I X$ y comienzos del $X X,{ }^{7}$ además de una concepción «realista» del documental que buscaba registrar al indígena concreto, físico, que desaparece ante sus propios ojos. ${ }^{8}$

A partir del siglo XXI la producción audiovisual indígena rompe con la visión histórica, objetivizante y expositiva que ha caracteriza-

7 Odone y Mason (Ed) 2002.

8 Gran parte de la producción audiovisual sobre el tema fueguino se basa en la utilización de materiales visuales que denotan un contacto directo y real con lo fueguino. El más importante es la obra de De Agostini, y los registros fílmicos realizados durante la expedición de Lipschutzal Archipiélago Fueguino en 1946; si algún día son encontrados (Lipschutz 1950:5, sólo referencias escritas). Además, existen breves imágenes de Yaganes y Alacalufes incluídas en el film de Rafael Sánchez en su documental «Chile Paralelo 56» (1964/16mm/23'). En Argentina Anne Chapman, J orge Preloran y Ana Montes realizaron «Los Onas, Vida y Muerte en Tierra del Fuego» (1977 / 50'), con entrevistas a descendientes e informantes claves. Después, aparecen los trabajos expositivos/pedagógicos de Ernesto Luis Piana «Etnoarqueología de los canales fueguinos» (1988 / 27') y «Humo en los ojos, Yámanas de Tierra del Fuego» (1997 / 25') ilustrados con abundante material fotográfico, al igual que Carlos Varacca y su trabajo «ONAS: Exterminio de un mundo» (Museo del Fin de Mundo 1996/33'). Finalmente, y desde una perspectiva más contemporánea nos encontramos con el trabajo de Manuel Valdivia «Enriqueta, la última Selk'nam» (1996 / 30'). Quien entrevista a una descendiente fueguina que habitaba en Ushuaia. En 1990 Anne Chapman realiza una segunda producción audiovisual «Homenaje a los Yaganes: los indios de Tierra del Fuego y Cabo de Hornos», en co-produccion con la televisión Italiana. Lo que denota una visión «realista» en el rescate, construcción y difusión audiovisual del indígena fueguino.

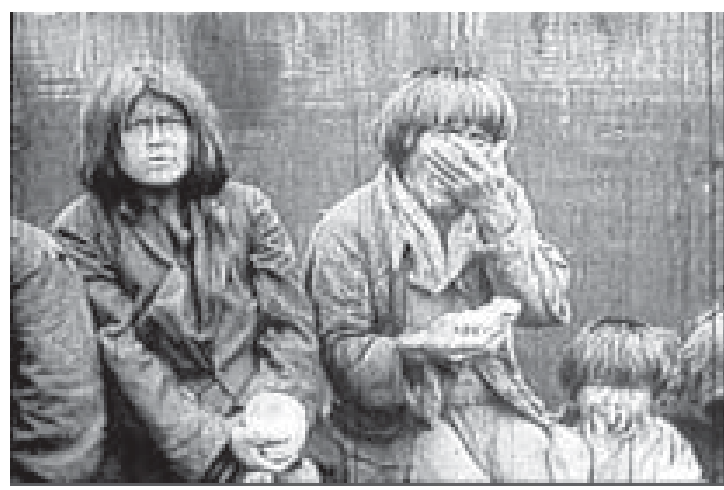

Fig. 1b. Fotograma de la película de Alberto M. De Agostini.

do al documental y plantea un documental fueguino subjetivo y reflexivo que enriquece la realidad, entregando nuevos puntos de vista de una misma realidad. ${ }^{9}$

Entre los años 2001 y 2003 se realizaron cinco documentales indígenas, de los cuales tres abordan el tema indígena fueguino constituyendo nuestro Universo de Estudio denominado «documental fueguino». ${ }^{10}$ Estas películas son La última huella (2001/65') de Paola Castillo, Yikwa ni Selk'nam (nosotros somos los Selk'nam) (2002/ 50') de Christian Aylwin, y Estrecho de Magallanes. (Des)Encuentros de dos miradas (2003/ 60 ') de Hernán Dinamarca.

Obras audiovisuales que abordan la temática indígena fueguina a través de un lenguaje cinematográfico más simbólico y no tan indicativo, más reflexivo y no tan expositivo. Creando algunas confusiones sobre la verdadera particularidad del documental como narración objetiva y sobria de la realidad. ${ }^{11}$

Este trabajo de análisis sobre el «documental fueguino del siglo XXI» se enmarca dentro de una Antropología del Cine, incipiente en el ámbito de la Antropología Visual, y que a diferencia de muchos trabajos de crítica e interpretación cinemática, que abordan las películas desde una apreciación histórica, esta investigación pretende analizar las películas a partir de su estructura fílmica.

9 Paola Castillo (entrevista realizada el 5 / 7 / 2005 por Margarita Alvarado, María Paz Bajas y Felipe Maturana).

10 Para más información sobre criterios de selección y universo de estudio, ver Anexo 2.

11 Nichols 1997. 


\section{CONCEPTOS Y METODOLOGÍA}

La metodología empleada para el análisis de este material audiovisual proviene de los planteamientos de Sergei Eisenstein, padre de la teoría del montaje, quien señala la necesidad de analizar películas en tres niveles. El primer nivel lo denomina Plano General (PG), y busca dar cuenta de la percepción global de un film. El segundo nivel de análisis es el Plano Medio (PM), el cual subraya los aspectos temáticos y emocionales de las películas. Y el tercer nivel de análisis es el denominado Primer Plano (PP), y corresponde a una deconstrucción microfílmica «que pueda estudiar la condensación de las líneas fuerzas que constituyen el film del que se extirpa». ${ }^{12}$

Sin embargo, ¿qué entenderemos por Plano $G$ eneral (PG) o percepción global del film?. Si revisamos el trabajo realizado por Alicia Vega ${ }^{13}$ encontramos los términos de «argumento y «estructura dramática» que nos permiten operacionalizar el análisis en Plano General (PG) propuesto por Eisenstein.

El término «argumento» hace referencia a una serie de hechos conectados lógica y cronológicamente. Son la materia prima, o el esquema básico, de la historia anterior a su organización artística. Según Todorov la «historia» (0 argumento) evoca una cierta realidad, son acontecimientos que habrían sucedido, existen personajes que se confunden con los de la vida real. ${ }^{14}$ Sin embargo, no hay que creer que la «historia» (o argumento) corresponde a un orden cronológico ideal, sino más bien a una convención que no existe a nivel de los acontecimientos mismos. En este sentido, la historia sería un constructo imaginario creado progresiva y retroactivamente por el espectador. ${ }^{15}$

En cambio, el término «estructura dramática» hace referencia a la deformación del orden causal-cronológico de los hechos en una organización artística de la historia en una trama. Todorov denomina a esta dimensión como «discurso » en referencia a la existencia de un narrador. En este nivel no son los acontecimientos re-

12 Eisenstein «En gros plan» 1974 (fue escrito originalmente en 1945 en Isskoustvo Kino, y republicado en 1974 en «Au dela des étoiles O euvres». Tomo I. París. U.G.C.) en Zunzunegui 1996:14.

13 Vega et al. 1979.

14 Todorov 1991.

15 Stam et al. 1999:93. feridos los que cuentan, sino el modo en que el narrador nos los hace conocer. ${ }^{16}$

En cuanto al Plano Medio (PM) Rafael Sánchez señala que «to do film, largo o cortometraje, debe estar dividido, para lograr así mayor claridad en la expresión y el desarrollo de su idea central». ${ }^{17}$ Las unidades mayores de una película son las secuencias, las cuales han sido definidas como «una de las grandes divisiones de un film, que posee un sentido completo. Se la puede comparar con el capítulo de una obra literaria».18 Un segundo concepto importante de tener en cuenta es lo que Alicia Vega llama «lenguaje cinematográfico», término que hace referencia al punto de vista del realizador y como este utiliza distintos mecanismos (procedimientos) de representación visual para conducir al espectador hacia reflexiones o sentimientos determinados. ${ }^{19}$

Para el análisis en Primer Plano (PP), se dividió el film en su unidad mínima, el plano, conceptualizado como un fragmento del film rodado en continuidad y delimitado por dos cortes: el de entrada y el de salida. Posteriormente, a cada plano se le asignó un rótulo 0 «motivo»20, y una serie de atributos como por ejemplo su duración, encuadre, movimiento de cámara, sonido, efectos, y presencia o ausencia de «narrador en off $»^{21}$ entre otros. Toda esta información fue ingresada a una base de datos para su posterior procesamiento en términos cuantitativos. ${ }^{22}$

En términos cualitativos, se utilizarán los términos de «puesta en cámara» y «montaje» propuestos por Vega. El primero hace referencia a la particularidad de la imagen en relación a su movimiento, estética, soporte, y sus connotaciones psicológicas en el espectador (dispositivos), mien-

16 Todorov 1991:161. Cabe señalar, que esta distinción entre historia y discurso, tienen sus raíces en los conceptos de fábula y syuzhet desarrollados por los formalistas rusos a principios del siglo XX (Victor Shklovsky 1927).

17 Sánchez 1971.

18 Idem: 53.

19 Vega et al. Ibid.

20 Motivo: Todo elemento importante que se repite en una película. Un motivo puede ser un objeto, un color, un lugar, una persona, un sonido e incluso un modelo de iluminación o a una posición de cámara si se repite a lo largo de toda la película (Bordwell y Thompson 1995:57).

21 Narrador en off: Discurso o texto extradiegético que orienta la lectura de las imágenes y los discursos en un film.

22 Metodología desarrollada por el Proyecto FONDECYT № 1030029, en base a metodologías arqueológicas. 
tras el segundo, "montaje", esta preocupado de la deconstrucción visual de alguna secuencia, escena o fragmento de la película que nos permita conocer los procedimientos visuales utilizados por el realizador. ${ }^{23}$

\section{ANÁLISIS}

III.1. "La última huella" (2001/65'), Paola CastiIlo

\section{En plano general (PG)}

"La última huella" es el primer documental chileno que aborda la temática indígena fueguina. ${ }^{24}$ Estrenada en el año 2001, ha sido exhibida en varios Festivales nacionales e internacionales, y emitida por televisión abierta con muy buena recepción y crítica en general.

A nivel del argumento la película es una construcción visual que nos presenta a Úrsula y Cristina Calderón, como las dos últimas descendientes de una cultura que se desvanece. Este sentimiento de pérdida es la carencia que permite articular una intriga que sostiene al relato. ${ }^{25}$

A nivel de la estructura dramática de "La última huella", destacamos los créditos iniciales que dan cuenta de una serie de instituciones y organizaciones que participaron en esta realización audiovisual, algo que ya parece casi una norma por no decir una obligación como es el caso del FONDART. Aquí aparecen la ADOC (Asociación de Documentalistas de Chile), el FONDART (Gobierno de Chile), CENECA, ${ }^{26} \mathrm{y}$ ERRANTE Producciones quienes presentan la película. Después aparece un mapamundi que nos lleva lentamente hasta el último confín del mundo. En la medida que avanza este mapamundi aparece el texto introductorio, subiendo sobre el

23 Vega 1979.

24 No fueron incluidos las obras de De Agostini (1930 aprox.), Sánchez (1964) ni Sanhueza (1992) antes mencionadas. La primera, por no ser una película chilena, la segunda por no abordar «decididamente» el tema indígena, y la tercera por no existir copias disponibles para su visualización y análisis.

25 Según Propp «La primera función en un cuento es la Fechoría (A) o la Carencia (a), ella es la que genera la intriga rompiendo el equilibrio inicial». (1981:42 [1928])

26 Señalemos que CENECA (Corporación de Indagación y Expresión Cultural y Artística) publico la investigación «Re-visión del Cine Chileno» (1979) dirigida por Alicia Vega, uno de los primeros trabajos de análisis fílmico.

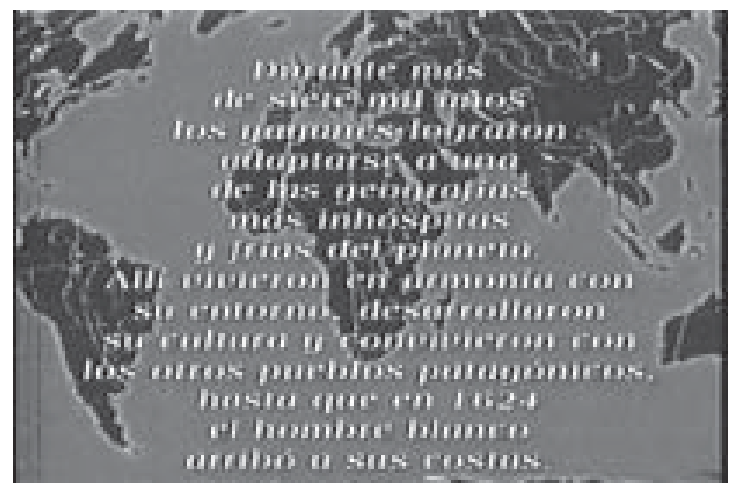

Fig. 2. Fotograma de la película "La última huella".

fondo, que nos cuenta la historia de un pueblo que supo «adaptarse a las geografías más inhóspitas del planeta». Se refiere al pueblo yámana, quienes «allí vivieron en armonía con su entorno... hasta que en 1624 el hombre blanco arribó a sus costas... Hoy sólo quedan dos hermanas (U rsula y Cristina)... Estas mujeres son la memoria que conecta a su comunidad, descendientes del pueblo yagán, con su pasado y su idioma». ${ }^{27}$

Sobre este texto, la propia autora reconoce que es heredera de una educación que le enseñó lo indígena como algo pasado, extinto. Principios y valores que de una u otra manera ella repite en su obra audiovisual al utilizar frases como allí vivieron, cuando en realidad aún viven. ${ }^{28}$

Mención aparte merece el título, «La última huella», pues no es el primero, ni será el último video que señala ser un registro del último individuo de una cultura fueguina. En Punta Arenas se realizó un documental televisivo (TVN Punta Arenas) titulado «Fresia, la última Alacalufe». Y en Ushuaia (Argentina), el realizador audiovisual Francisco Valdivia realizó un breve documental sobre «Enriqueta, la última Selk'nam». ${ }^{29}$ Títulos que de una u otra manera buscan realzar el trabajo de rescate cultural del documental, pero que ha sido duramente criticado en el ambiente indígena pues niega, de una u

27 Texto al inicio del documental «L a última huella» (Plano 001 , duración 65,3 segundos).

28 Entrevista realizada el 5 / 7 / 2005 por Margarita Alvarado, María Paz Bajas y Felipe Maturana.

29 Información Obtenida durante trabajo de campo, Diciembre 2003. 
otra manera, la posibilidad de ser o sentirse indígena a todos aquellos sujetos que viven actualmente en el territorio fueguino, y que son descendientes mestizos de yámanas, kawesqar y/o selk'nam.

\section{En plano medio (PM)}

En general podemos observar que la película, en términos de lenguaje cinematográfico, se compone de por lo menos de 11 secuencias en una aproximación que va desde lo general, emplazamiento geográfico, a lo particular, memoria fotográfica. ${ }^{30}$ Este desarrollo lineal y progresivo se encuentra entrecruzado por elementos reiterativos que nos permiten ir construyendo una historia fragmentada, llena de reminiscencias. Nos referimos a las imágenes de paisaje, al narrador en lengua yámana subtitulado en español, a las imágenes fotográficas de fines del siglo XIX e inicios del XX, a los fragmentos de la película de $\mathrm{De}$ Agostini, y a las imágenes de U rsula y Cristina en blanco y negro al final de cada secuencia, que junto a una banda sonora evocativa rompen la dimensión netamente denotativa.

De esta manera encontramos un relato audiovisual que explora en la dimensión connotativa, a partir de la dicotomía «valores positivos de la cultura yámana en tiempos pasados», asociados visualmente al blanco y negro propio de una visualidad fotográfica antigua v/s «la pérdida de estos valores en la sociedad actual», asociada a imágenes en colores y lugares vacíos.

\section{En primer plano (PP)}

A nivel microfílmico destacamos la categoría «Descripción del Sonido» que se aplicó a cada uno de los planos de la película. Por ejemplo, de los 56 planos que componen la cuarta secuencia ( $\mathrm{SO4}$ ) sólo 5 contienen sonido sincrónico con la imagen, 40 presentan un sonido diacrónico o sin sincronismo con la imagen, y 11 son una mezcla de ambas. Esta propuesta audiovisual de utilizar un audio no sincrónico construye una atmósfera que nos aleja del aquí y del ahora, facilitando nuestro viaje de búsqueda de la cultura yámana en un tiempo pasado.

Otro elemento importante es la presencia

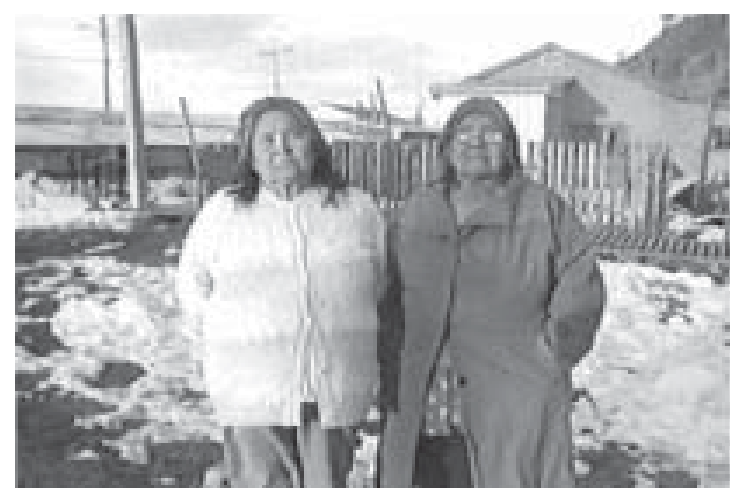

Fig. 3. Fotograma de la película "La última huella".

de efectos de b/n sobre imágenes actuales de Ursula y Cristina Calderón al final de cada secuencia, lo que nos produce una vinculación inevitable con las imágenes captadas hace más de medio siglo, sean estas fílmicas o fotográficas. De esta manera la realizadora nuevamente nos reafirma su idea de ver a las hermanas Calderón como un puente que permite unir el presente con el pasado, a través de una visualidad fotográfica (b/n). Esta conexión, entre lo presente y lo ausente, es sin duda la dicotomía estructural de esta película documental fueguina, incluso en términos visuales.

En relación a los 26 motivos encontrados en esta película, no existen grandes concentraciones, sino por el contrario una distribución homogénea y equilibrada. Sin embargo, toma relevancia la figura de Ursula y Cristina, las imágenes de paisaje y las fotografías de principio de siglo. ${ }^{31}$ Lo primero nos habla del protagonismo de las hermanas Calderón como eje articulador de la narrativa audiovisual. El segundo, opera a nivel de la estrecha vinculación que existe entre indígenas y la naturaleza (motivo paisaje). Y por último, la recurrente utilización de imágenes fotográficas del siglo XIX, principalmente las obturadas por la Misión Científica al Cabo de Hornos (1882-83), que anclan nuestro imaginario en una visualidad iconográfica que tiene sus primeros antecedentes en los primeros grabados sobre indígenas fueguinos realizados «in situ». ${ }^{32}$

Un punto importante en la utilización de

31 Ver Anexo 1, Tabla 2.

32 Mason 2002. 


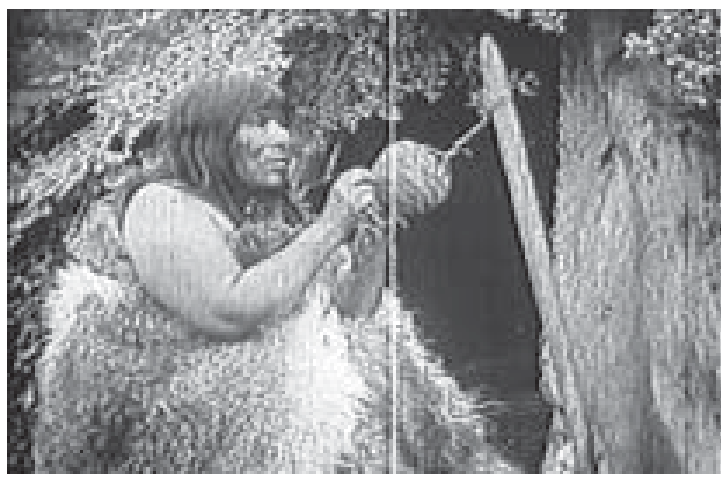

Fig. 4a. Fotograma de la película de Alberto $M$ De Agostini utilizados en la película "La última huella".

material de archivo, tanto fotográfico como filmográfico, son las imágenes de Rosa Yagán, tejiendo un cesto típico yámana, y después pintando a una niña con pintura facial con diseño típicamente yámana, junto a una choza típica yámana, pero vestida con cueros de guanaco, típicamente selk'nam y no yámana (Fig. 4). Además, estas imágenes de la abuela Rosa, capturada por De Agostini a principios del siglo XX en los alrededores de Ushuaia, han sido históricamente etiquetadas como mujer selk'nam pues en el montaje se encuentran yuxtapuestas a imágenes de una mujer Selk' nam trabajando el cuero. En este sentido la recontextualización de estas imágenes, al interior de la cultura yámana, es una deuda histórica saldada por la realizadora. Actitud que, de una u otra manera, se opone a la práctica audiovisual de utilizar imágenes indiscriminadamente para ilustrar al indígena sin importar su filiación étnica.

III.2. "Yikwa ni Selk'nam (nosotros somos los Selk'nam)" (2002/50'), Christian Aylwin.

En plano general (PG)

El territorio fueguino es fructífero en imaginarios, y ha inspirado cientos de relatos e historias que ocurren en estas lejanas tierras del fin del mundo. Los selk'nam han sido por siempre sus protagonistas, los valientes y bellos cazadores de guanaco, quienes con su técnica ancestral, arco y flecha, han convivido por miles de años en armonía con la naturaleza. Hasta que el hombre blanco y su civilización devastadora los exterminó. Con ello, su expresión más sublime, sus

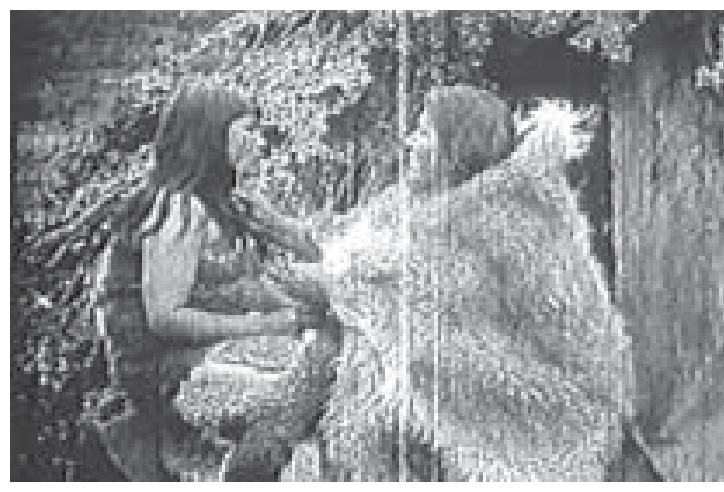

Fig. 4b. Fotograma de la película de Alberto $M$. De Agostini utilizados en la película "La última huella".

cuerpos pintados y su cosmogonía, también desaparecieron. Sin embargo, antes de su extinción cultural, Martín Gusinde, misionero y etnólogo, por encargo del Museo de Etnología y Antropología 33 realizó un registro etnográfico sobre los grupos culturales selk'nam, yámanas (o yagán) y kawesqar. Los mitos y creencias, recolectados por Gusinde, junto a las fotografías por él obtenidas, entre 1918 y 1924, constituyen la principal fuente de información que organiza este documental.

Sin embargo, cuando visualizamos la película Yikwa ni Selk'nam (Nosotros somos los Selk'nam), nos llama profundamente la atención la manera poco convencional de construcción audiovisual para un documental indígena. Pues en él no encontramos ningún registro directo de la realidad, excepto aquellos registros fotográficos y fílmicos de finales del s. XIX y principios del $X X$ que aparecen fragmentariamente en la película. Su propuesta discursiva, o estructura dramática, se acerca a las artes visuales, lo cual presupone a un espectador activo en la construcción de nuevas significaciones a partir de la ruptura de las cadenas significantes, ${ }^{34}$ tanto a nivel de yuxtaposición de imágenes como en relación al texto y la banda sonora.

Si consideramos los tres puntos de vista propuestos por Nichols para definir un documental 1) realizador, 2) texto y 3) espectador, podemos señalar que 1) el grado de control que pue-

33 Fundado en 1912, en el antiguo edificio de las Monjas Claras en Moneda frente a la plaza Vicuña Mackenna, y cuyo primer director fue Max Uhle. Publicaciones del Museo de Etnología y Antropología, Año 1, nํ1, 1916.

34 Downey 1987. 
de ejercer el realizador sobre su tema, es semejante al de construcciones argumentales o de ficción, y opuesto al documental clásico que interactúa con sus protagonistas. ${ }^{35}$ En cuanto a la dimensión de texto visual, 2) podemos señalar que este film no comparte muchas de las convenciones que identifican a un documental como tal, pero sí comparte la búsqueda de una narración de un mundo histórico, fundamentado a través de una investigación, y recreado audiovisualmente. Esta nueva forma de entender el documental, nace del continuo proceso de transformación de los géneros, y sus influencias mutuas que ha provocado el nacimiento de nuevos géneros como el «docudrama» y el «documental falso». ${ }^{36}$ En cuanto a la dimensión del espectador, 3) la obra analizada ha sido exhibida en distintos festivales de documentales, entre los que destaca el 60 Festival Internacional de Documentales de Santiago (FIDEDOCS 2002, competencia nacional).

Pero ¿de qué trata la película de Christian Aylwin?, 0 ¿cuál es su argumento?. Una posible respuesta sería: trata sobre los mitos del pueblo Selk'nam, y su ceremonia de iniciación, el Hain. Pero, ¿estos temas constituyen en sí un argumento de una película?. Lo que hace que una película sea narrativa, y tenga un argumento o una historia, es la existencia de acciones, o funciones, generalmente interrelacionadas bajo el principio de causa y efecto. Estas acciones ordenadas, e incluso articuladas en varios niveles, construyen una estructura en la cual el espectador debe retener información, anticipar acciones, y convertirse en un ser activo en la construcción cinematográfica. ${ }^{37}$

En términos argumentales, la película estudiada aborda, por lo menos, tres grandes mitos y/o creencias del pueblo Selk'nam de forma explícita a través de un «narrador en off». El primero de ellos es sobre el mito de origen del pueblo selk'nam en el cual Timaukel envía a Kenos a repartir el mundo y a crear a los Selk'nam a partir de dos genitales hechos de barro. El segundo

35 Nichols 1997:42

$36 \mathrm{El}$ primero toma las convenciones y narratividad de la puesta en escena en favor de la reconstrucción documentada y del desarrollo del «punto de vista» (J ean Vigo), mientras el segundo utiliza los dispositivos visuales del documental, como la cámara en mano, en favor de una mayor verosimilitud de la historia narrada.

37 Propp 1981 [1928]. relato trata sobre el engaño que las mujeres hicieron a los hombres en tiempos en que Luna y Sol vivían en la Tierra, y el cual da origen a la ceremonia del Hain y al gran secreto de los Selk'nam contado generación tras generación que aparece rítmicamente en las narraciones S05, S06, S08 y S10. ${ }^{38}$ El tercer y último mito cuenta la historia de la egoísta y despiadada Táita, de la cual el pueblo Selk'nam obtuvo el arco y la flecha, y que trae consigo una moraleja para aquellos que cultivan el egoísmo y la crueldad entre y para los Selk'nam.

Sin embargo, estas tres narraciones no logran construir o trenzar una historia, o mejor dicho una intriga, que tenga una estructura dramática con un desarrollo y un desenlace. Por el contrario, nos propone una mirada fragmentaria, que interpela al espectador en la construcción conjunta de un sujeto indígena fragmentario y culturalmente distinto.

\section{En plano medio (PM)}

En general podemos señalar que la película «rikwa ni Selk'nam» se inicia con un texto introductorio que fija el dominio temático (historia, geografía, mitos y ceremonias del pueblo selk'nam), un elemento de quiebre (grabado y crónicas del descubrimiento de América), y el título que propone una mirada desde el interior del pueblo Selk'nam, perspectiva emic, que se deduce a partir de la frase «nosotros somos los Selk'nam» (subtítulo).

Después de este segmento introductorio, neutro o mejor dicho extradiegético, la película puede ser descompuesta en dos grandes relatos: uno silencioso o subjetivo, y el otro narrado. El primero, ocupa un $55 \%$ del tiempo del film, y sus imágenes no muestran acciones que nos permiten construir relaciones de causa y efecto como ocurre en numerosas películas mudas, que pese a no tener narrador o textos explicativos, logran transmitir un mensaje sin problemas. $Y$ es que "Yikwa ni Selk'nam" esta construido a partir de yuxtaposición de imágenes, textos y banda sonora que buscan en el espectador generar nuevos significados. En este sentido la película más que narrar busca que el espectador experimente sensaciones.

38 Ver Anexo 1, Tabla 3. 


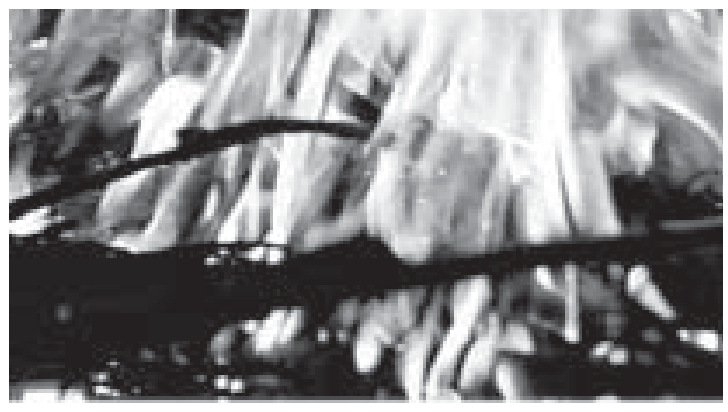

Fig. 5. Fotograma de la película "Yikwa ni Selk'nam".

En primer plano (PP)

De los 486 planos que constituyen la película «rikwa ni Selk'nam», el motivo más reiterado fue la fotografía en blanco y negro, de principios del 1900, obturada por fotógrafos como Charles W. Furlong (1907-1908), Martín Gusinde (1918-1924), y Alberto María De Agostini (19101930) principalmente. Sin embargo, los motivos más significativos en relación al tiempo de exhibición son sin duda los paisajes, los cuales ocupan cerca del $25 \%$ del tiempo que dura la película sin los créditos finales. ${ }^{39}$ Otro motivo importante de señalar es la presencia o ausencia de narrador en off, el cual se encuentra presente casi en un $45 \%$ del tiempo de la película, más de 20 minutos, y estrechamente asociado al motivo visual del fuego; tercero en importancia desde el punto de vista de su duración (Fig. 5) ${ }^{40}$.

En este sentido el fuego es la construcción más significativa, y particular de este film. Pues en ella se relata el mito central de esta película, que explica el porque los hombres se pintan y usan máscaras para asustar a las mujeres y niños. Historia que es contada en susurro para que las mujeres y niños no escuchen pues se trata de un gran secreto. Es una recreación subjetiva de la trasmisión de la tradición oral en la cultura Selk'nam.

Muchos de los motivos asociados al narrador, como el fuego, tienen como particularidad una visualidad en blanco y negro, detectada a través de la categoría «efectos de imagen», pues señalemos que nosotros no observamos el mundo exterior en blanco y negro. En este sentido el dispositivo visual que permite relacionar el blan-

39 Ver Anexo 1, Tabla 4. 40 Ver Anexo 1, Tabla 5

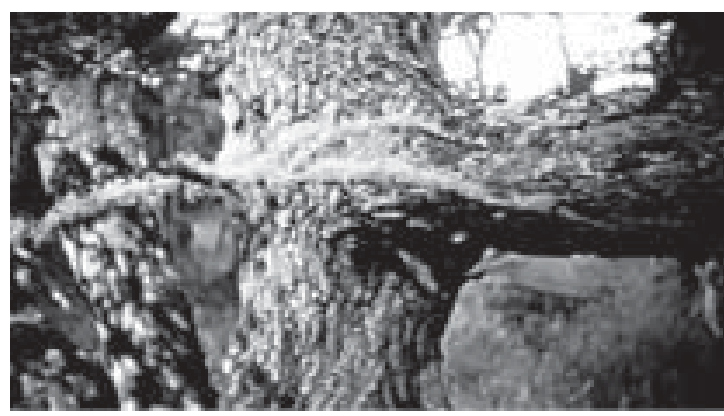

Fig. 6. Fotograma de la película "Yikwa ni Selk'nam".

co y negro, con lo indígena en tiempos pasados, fue construido a partir de la obturación, circulación y consumo de las primeras fotografías y cine etnográfico asociado técnicamente al blanco y negro.

Esta construcción de lo indígena como una forma distinta de percibir el mundo se ve reafirmada por la utilización de paisajes acelerados (paso rápido del tiempo) y por la utilización de primeros planos a la vegetación fueguina, asociados a una cámara subjetiva (cámara en mano y gran angular) que denota una mirada cercana del indígena con la naturaleza (Fig. 6).

III.3. "Estrecho de Magallanes. (Des) Encuentros de dos miradas" (2003/60'), Hernán Dinamarca

En plano general (PG)

La película "Estrecho de Magallanes" se inicia con un cartel de reconocimiento al FONDART, Gobierno de Chile, el cual financió la obra de Dinamarca en el año 2002. Esta película es la más reciente de las películas indígenas referida a los grupos indígenas fueguinos, fue realizada en la ciudad de Punta Arenas, lugar de residencia del realizador y su distribución ha sido más bien local. Realidad que lo diferencia de las dos realizaciones anteriores las cuales fueron hechas por un equipo eminentemente santiaguino (ciudad capital de Chile), lo que trae como consecuencia que este documental no sea de fácil acceso, por lo menos para nosotros los capitalinos.

En términos generales, la película es un docudrama que recrea el testimonio y las vivencias experimentadas por Pedro Sarmiento de Gamboa a fines del 1500 en el Estrecho de Magallanes. Su «argumento» relata las aventuras 


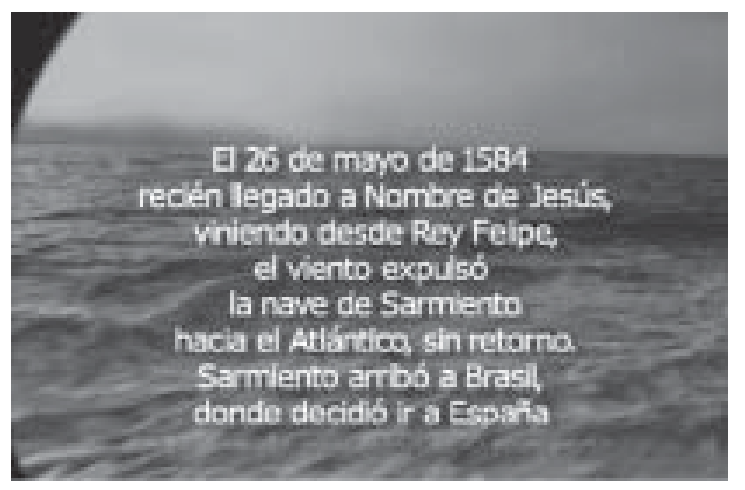

Fig. 7. Fotograma de la película "Estrecho de Magallanes".

del conquistador español, representado por Mauricio Quercia (Director del Museo Regional de Punta Arenas), y es el único personaje/actor que aparece en cámara. El otro sujeto que articula el argumento es el indígena que habitó ese lugar, en armonía con el entorno y con sus dioses, desde tiempos pretéritos hasta la llegada del conquistador (idea expresada en el texto introductorio de la película). A nivel de su «estructura dramática», se representa a un sujeto fueguino encarnado por una cámara subjetiva en blanco y negro, en yuxtaposición con las imágenes fotográficas y registros fílmicos de fines del siglo XIX y comienzos del XX ya mencionados. Además de la utilización de carteles intercalados que expresan su cosmovisión y mitología, en oposición a los textos declamados por el conquistador español.

\section{En plano medio (PM)}

Cada capítulo o secuencia de la película esta altamente estructurada, todas ellas a excepción de la presentación (S01) y el epílogo (S09) se inician con un cartel que señala el número del capítulo y su título, seguido de una imagen de mar vista desde un barco en viaje sobre la cual aparece un texto histórico, en roll-up, relatando el desarrollo cronológico del descubrimiento, coIonización y desventura de Sarmiento de Gamboa en el Estrecho de Magallanes (Fig.7) ${ }^{41}$. Lo que sigue a continuación de este estructurado comienzo es una combinación variable de los siguientes elementos: 1) Imágenes en color, subjetivas u observacionales, que nos ilustran el pensar y vi- vir de Sarmiento de Gamboa. 2) Ligadas al acontecer de este colonizador español están las imágenes de paisajes en colores. 3) Un tercer elemento son los textos que relatan la historia, vida y creencias de los distintos pueblos indígenas que habitaron este lugar. Nos referimos a los Aonikenk, Selk'nam, Haush, Kawesqar y Yámanas. 4) Y por último, están aquellas imágenes en $b / n$ que representan la mirada subjetiva del indígena yuxtapuestas con fotografías antiguas y fragmentos de la película de De Agostini.

En relación al término «C apítulo» utilizado por el realizador al inicio de cada secuencia, hace referencia a la idea de un libro. Es más, la transición que emplea para empezar cada capítulo es como si estuviésemos dando vuelta una hoja, llamado técnicamente «transición de corte directo», en oposición a la «transición de fundido encadenado » que implica un paso gradual de una imagen a otra. Todo esto guarda relación con la idea de estar estudiando un texto antiguo, muy similar a las crónicas de los viajeros que por primera vez llegaron a este rincón del mundo. Por ello, no nos extraña que el protagonista de este relato sea el conquistador español, y su opuesto, el indígena.

\section{En primer plano (PP)}

En relación a los motivos utilizados en la narración fílmica aparece con gran persistencia la mirada subjetiva del conquistador español, tanto en el número de planos como en su duración. Este motivo «subjetivo» esta estrechamente relacionado con el motivo «Actor Españo|», por lo tanto se han unificado como una gran categoría dentro del análisis final denominada «Subjetiva + Conquistador».42

Un segundo motivo importante son las fotografías en blanco y negro que junto con los fragmentos de la película de De Agostini constituyen la segunda mayoría en la cantidad de planos. Al igual que en las películas de Castillo y Aylwin, Dinamarca ocupa los mismos fragmentos fílmicos de De Agostini más algunos otros relacionados con los Salesianos y el mundo Aonikenk. Sin embargo, a diferencia de Castillo y Aylwin, Dinamarca no busca dar cuenta de un grupo cultural específico, sino del mundo indígena fueguino en general. Por lo tanto, las imágenes pasan de un 


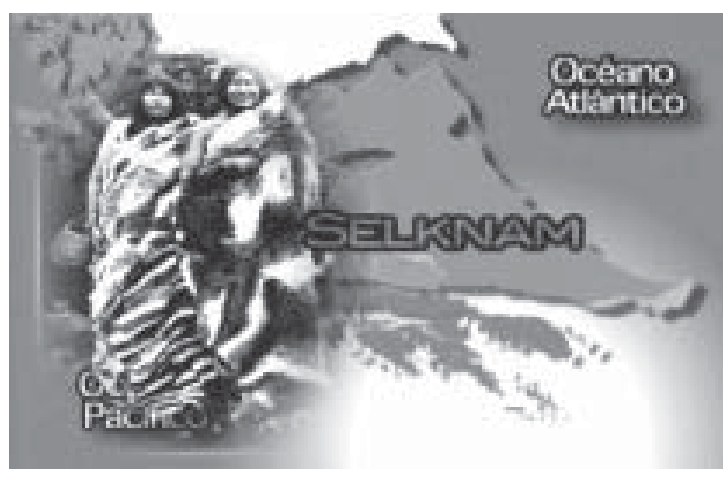

Fig. 8. Fotograma de la película "Estrecho de Magallanes".

grupo cultural a otro sin mayor distinción que la realizada geográficamente al inicio del video (Fig. 8).

El tercer motivo en importancia es el «paisaje», el cual permite al realizador desprenderse de la interpretación histórica que a través de los textos en pantalla, texto indígena y texto histórico, constantemente refuerzan el desarrollo cronológico de la historia y construyen el sentido general de la obra. De esta forma el paisaje aparece asociado a la libertad interpretativa, a la evocación y a los sentimientos en oposición a los pensamientos lineal y articulado. Pues cabe señalar, que junto a las imágenes de paisaje aparece una banda sonora evocadora que construye una atmósfera que nos permite descansar del discurso constante expresado a través del «narrador en off», del texto escrito, y/o del argumento declamado por el actor protagonista que construyen un lenguaje audiovisual a veces demasiado literal.

En los seis capítulos que construyen el nudo del argumento de esta obra audiovisual se observa un riguroso orden sistemático y métrico, pues muchas de las unidades se repiten en el orden, en sus duraciones, en el tipo de transiciones y en su lógica discursiva. Por ejemplo, todas las secuencias narrativas, a excepción de la presentación (S01) y el epílogo (S09), se inician con un cartel que exhibe el nombre de la secuencia seguida de un texto histórico que sube sobre un fondo constante (el mar visto desde un barco en viaje). Todo esto construye una percepción de uniformidad del relato, la cual el espectador puede anticipar fácilmente sin miedo a equivocarse. Lo que produce una cierta monotonía y aburrimiento por parte de un espectador ávido de quiebres narrativos y audiovisuales.

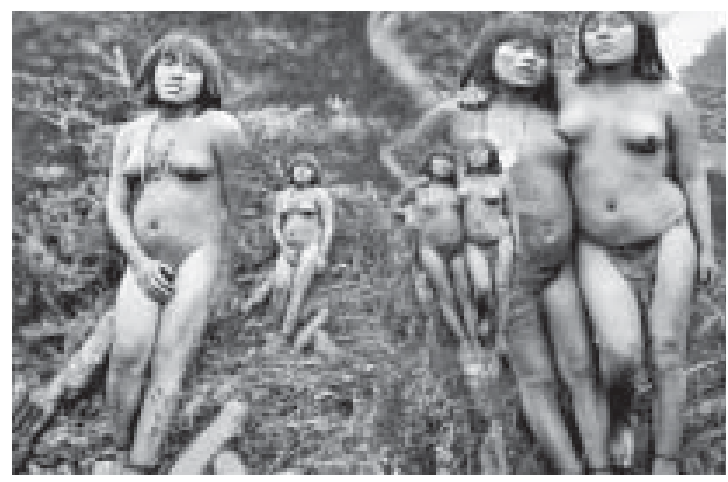

Fig. 9. Fotograma de la película "Estrecho de Magallanes".

Sin embargo, para compensar esta monotonía constructiva el realizador utiliza recursos audiovisuales poco tradicionales para el género documental. Por ejemplo, la puesta en escena o actuación en un montaje dramático convierten a este documental en un docudrama. Por otro lado, el uso de gran angular es un recurso constante en el ámbito fílmico de la película, lo cual se traduce en que el $32 \%$ de los planos contienen un efecto de imagen que altera la percepción normal. ${ }^{43}$ Lo que contrasta con el $9 \%$ de planos con efectos en la película «La última huella», y acercándolo al 31\% de la película «Yikwa ni Selk'nam». Por ende, pese a esta aparente tradicionalidad del relato de la película «Estrecho de Magallanes», se observa una no tradicionalidad en el ámbito visual que tensiona al relato y refuerza la idea matriz de esta película "(Des) encuentro de dos miradas" (Fig. 9).

\section{ANÁLISIS COMPARADO}

En plano general (PG): Las tres películas buscan experimentar en el leguaje audiovisual rompiendo con las convenciones del documental de tres maneras distintas. Por un lado, Paola Castillo nos plantea una forma híbrida entre narración convencionalizada y construcción audiovisual evocativa. Trabaja la emotividad desde lo tangible, las últimas descendientes yámanas, y busca llegar a lo intangible, la cultura que se desvanece. Por otro lado, Christian Aylwin nos plantea una alteridad radical que debe ser decodificada, a través de claves audiovisuales inscritas en un lenguaje audiovisual, muy cercano a «las líneas de narración interrumpida" pro-

43 Ver Anexo 1, Tabla 7. 
puestas por Juan Downey que buscan "cortocircuitar los significantes para que los espectadores chisporroteen significados nuevos». ${ }^{44}$ En el extremo opuesto, en cierto sentido, Hernán Dinamarca busca una explicitación total a través de textos que orientan la lectura de las imágenes, con elementos de quiebre audiovisual que nos evoca algo más que lo evidentemente tangible. Elemento que de una u otra manera comparten estos tres documentales chilenos.

En plano medio (PM): un elemento importante de rescatar es que las tres películas incluyen un texto inicial que da cuenta de cómo vivían los indígenas en estos territorios, fijando el dominio temático en el cual transcurre la historia. Por

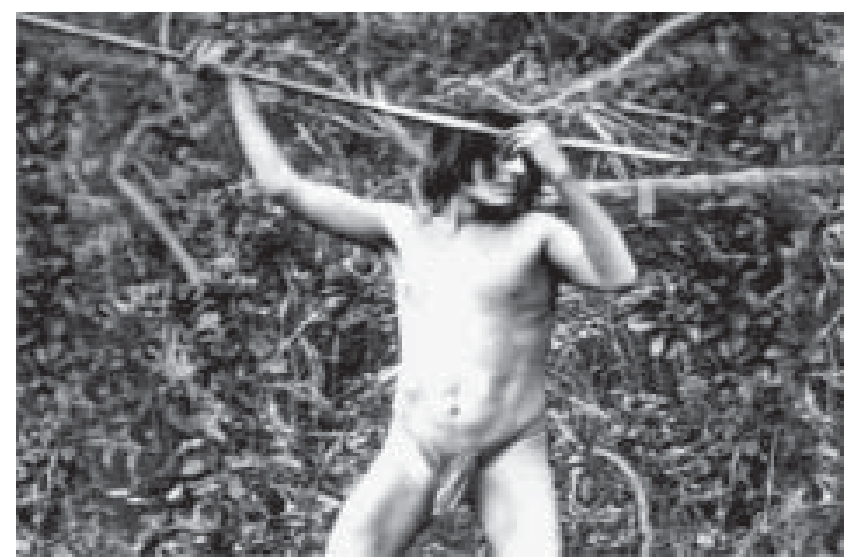

Fig. 10. Athlinata lanzado su arpón, fotografía publicada en 1891 , en el Volumen VII de la Misión Científica al Cabo de Hornos (1882-1883), utilizada en la película "Estrecho de Magallanes". ejemplo, en las tres presentaciones se repite la idea de que "el indígena fueguino vivió por miles de años en ARMONIA con su medio ambiente o entorno". Esta idea de armonía es uno de los aspectos más reiterados dentro de la concepción audiovisual con respecto al indígena en general, construyendo un verdadero patrón que se repite constantemente hasta convertirlo en estereotipo. Esto nos lleva a plantear que los valores propuestos por los realizadores audiovisuales en relación a los indígenas, más que un reflejo objetivo de esta cultura indígena, es un sentimiento de nostalgia y pérdida que proyecta nuestra propia cultura occidental a partir de la evidente ARMONIA que existiría entre la naturaleza y las culturas ancestrales como la fueguina. En este sentido, las obras aquí estudiadas son doblemente etnográficas pues hacen referencia a un otro indígena fueguino y al mismo tiempo entregan información cultural sobre los valores y creencias de los propios realizadores audiovisuales en diálogo con la sociedad chilena que los decepciona, al igual que toda reproducción visual de otro culturalmente distinto. ${ }^{45}$

En primer plano (PP): los motivos más importantes y recurrentes son Fotografía, Paisaje, y Subjetiva. ${ }^{46}$ El primer motivo, la fotografía, hace referencia a las imágenes de principio del siglo

44 Los efectos de imagen corresponden al campo 18 analizado en nuestra base de datos, y el cual busca dar cuenta de la presencia o ausencia de filtros y/o efectos de imagen en el plano (Fondecyt no 1030029).

45 Downey 1987.

46 Foerster et al. 1993.
$X X$, incluyendo el registro fílmico de Alberto $\mathrm{Ma}$ ría De Agostini, los cuales trabajan como un sólo referente solidario de un tiempo pretérito e idealizado de la cultura indígena. Imágenes que son tomadas como hechos verdaderos, sin mayor cuestionamientos, pese a que muchas de estas imágenes fueron producidas, dirigidas y montadas por los realizadores en función de satisfacer las necesidades del espectador, y no necesariamente dar cuenta de cómo eran los indígenas en esa época. Este mismo trabajo de montaje se ve reflejado en la obra de los realizadores quienes utilizan fotografías de distintos contextos en función de su relato, y no necesariamente coinciden con el sentido más profundo de la fotografía. ${ }^{47}$

Recordemos que cada vez que se busca mostrar al indígena en las tres películas se utilizan estas fotografías o primer cine etnográfico, por ello no dudamos en identificar lo indígena con el blanco y negro, incluso en la época actual. En la película "La última huella" es común pasar de fragmentos fílmicos en $b / n$ a escenas actuales en $\mathrm{b} / \mathrm{n}$ en donde las hermanas Calderón parecieran estar o pertenecer al pasado. Todo esto pone de manifiesto que el poder de persuasión visual de estas imágenes, obturadas hace más de un siglo, son de primer orden. Todo indígena es como el de las fotografías o del primer cine etnográfico:

47 Ver Anexo 1, Tabla 8. Cabe señalar, que esta cuantificación de motivos se hizo plano por plano en cada una de las películas, y no corresponde necesariamente al motivo de mayor duración. 
guerrero, exótico, místico, pretérito, y en blanco y negro.

Además señalemos, que muchas de las imágenes utilizadas por estas películas fueron obturadas por expedicionarios, aventureros e investigadores que buscaron derribar el mito del indígena fueguino como un ser salvaje, desprovisto de cultura, como señaló primero L'H eremite en 1624, y luego Darwin en 1842. De esta manera nos encontramos con hombres dignos, portadores de una cultura ancestral, tal como ocurre con las fotografías de la Misión Científica del Cabo de Hornos (publicada en 1891) donde Athlinata aparece lanzando su arpón, constituyéndose en el ícono de la cultura yámana. ${ }^{48}$ Filtro cultural que en cierta manera predetermina la visión del indígena fueguino (Fig. 10).

Un segundo motivo en importancia es la denominada Subjetiva, el cual nos plantea el interés de los realizadores por mostrar la forma particular, y distinta, de percibir el mundo por parte de un otro indígena, e incluso español en el caso de Dinamarca. De esta manera el realizador se convierte en una especie de médium que facilita la expresión subjetiva de los indígenas, y sus valores más ancestrales, provocando una anulación e invisibilidad del realizador que contrasta con la concepción de "video de autor" como gran comunicador expresando. ${ }^{49}$

Esta mirada subjetiva indígena, que se expresa a través de una cámara subjetiva, en gran angular y asociado a imágenes en blanco y negro, nos connota una mirada distinta de un otro totalmente distinto, pues ningún ser humano normal ve y observa en b/n. Es por ello, que no nos extraña que el tercer motivo en importancia de planos sea el Paisaje, símbolo de la armonía y equilibrio natural del indígena con su entorno y el cosmos (imágenes del Sol, la Luna, y las Estrellas son frecuentes en las tres obras analizadas).

\section{REFLEXIÓN FINAL}

Podemos señalar que las tres películas proponen tres formas representacionales distintas con un denominador común: la ruptura de las con-

48 Paola Castillo utiliza fragmentos de imágenes de Pierre Petit, obturadas en el Jardín de Aclimatación de París (1881), para ilustrar como vivían los antiguos yámanas.

49 Martín Gusinde en su publicación de 1937 utiliza la imagen de Athlinata en la portada del volumen Yámana. venciones del documental a nivel del lenguaje. Esta necesidad de romper con el lenguaje documental tradicional nace de la preocupación de los realizadores por entregar una mirada personal, subjetiva y documentada que se opone a la mirada objetiva y expositiva del documental tradicional. No buscan competir con la historia ni con la antropología, sino trasmitir su lectura personal de lo que fueron las culturas fueguinas. Pero ¿qué relación existe entre indígenas ausentes y nuevas formas de representación audiovisual? Es difícil establecer si son las preocupaciones temáticas las que llevaron a los realizadores a buscar nuevas formas de expresión cinematográficas, 0 es la evolución del lenguaje fílmico lo que permitió que hoy en día se abordara la temática fueguina en el documental chileno. Lo cierto es que el documental nacional ha experimentado una importante evolución a partir de mediados de los '90 cuando observamos las primeras trasgresiones del género documental. ${ }^{50} \mathrm{En}$ la actualidad, el trabajo documental se plantea como un desafío representacional que debe conjugar una historia legible (estructura narrativa), una mirada personal (punto de vista), y una profundidad temática (documentación). En el caso del documental fueguino dicha subjetividad, o punto de vista, es la del propio indígena que a través de los dispositivos visuales del blanco y negro, y la cámara en mano, buscan generar significados previstos como "el indígena vive en armonía con la naturaleza y los seres sobrenaturales". Representación audiovisual que no se aleja de otras representaciones audiovisuales indígenas. Dejando en claro que no basta sólo con romper con las convenciones del discurso o de la representación documental, sino que existe la urgencia de explorar en nuevos argumentos que vayan más allá del indígena como perteneciente al pasado y en armonía con la naturaleza.

\section{BIBLIOGRAFÍA CONSULTADA}

BARAHONA, FERNANDO ALONSO. 1991. Antropología del Cine. C.I.L.E.H., España.

BARTHES, ROLAND ET AL. 1991. Análisis Estructural del Relato, 8a Edición, Red de J onás. Premia Editora. México.

BORDWELL, DAVID Y KRISTIN THOMPSON. 1995. El arte cinematográfico. Paidos Comunicación 68 Cine. Ediciones Páidos Ibérica. S.A., España.

50 Torres 1987 
CORDERO, JAIME. 2001. Cinematos grafías, Colección Teoría, Depto. Teorías de las Artes, Facultad de Artes, Universidad de Chile. Dolmen Ediciones S.A.. Santiago, Chile.

DOWNEY, JUAN. 1987. El olor del aguarrás. En Video Porque Te Ve, Ediciones Visuala Galería pp. 9-11.

FOERSTER, R., S. MONTECINO y A. WILSON. 1993. Reflejos de Luna Vieja. Fondart, Chile.

LIPSCHUTZ, ALEJ ANDRO. 1950. La Clasificación racial de los fueguinos en Cuatro Conferencias sobre los indios fueguinos. Revista G eográfica de Chile, Santiago.

MASON, PETER. 2002. En tránsito: Los fueguinos, sus imágenes en Europa, y los pocos que regresaron. En 12 Miradas. Ensayos sobre los Selknam, Yaganes y Kawesqar. Odone y Mason (Ed). Taller de Cuerpos Pintados, Chile.

MATURANA, FELIPE. 2005 Fotografía Antropológica de Charles Wellington Furlong (Archipiélago Fueguino, 1907-1908). V Congreso Chileno de Antropología, Simposio de Antropología Visual, San Felipe (2004) . Revista Chilena de Antropología Visual, №5.

METZ, CHRISTIAN. 1991. La gran sintagmática del film narrativo. Análisis Estructural del Relato. En Barthes, Roland et al. Red de J onás. Premia Editora, México. pp.153-158.

MITRY, JEAN. 1990. La semiología en tela de juicio (cine y lenguaje). Ediciones Akal S.A., Madrid. España.

MOTSNY, GRETE. 1950. Transculturación en las tribus fueguinas en Cuatro Conferencias sobre los indios fueguinos. Revista Geográfica de Chile, Santiago.

NICHOLS, BILL. 1997. La representación de la realidad. Cuestiones y conceptos sobre el documental. Ediciones Páidos Ibérica S.A., España.

ODONE, CAROLINA Y PETER MASON (ed). 2002. $12 \mathrm{Mi}$ radas. Ensayos sobre los Selknam, Yaganes y Kawesqar. Edición Taller Cuerpos Pintados, Santiago de Chile, $467 \mathrm{p}$.

PIAULT, MARC HENRI. 2002 [2000]. Antropología y Cine. Ediciones Cátedra. G rupo Anaya, S.A., Madrid, España.

PORTAS, JUAN CARLOS. 2001. Patagonia, cinefilia del extremo austral del mundo. Ed. Universitaria de la Patagonia, Argentina.

PROPP, VLADIMIR. 1981 [1928] Morfología del cuento. Ed. Fundamentos. Madrid. España.

RICOEUR, PAUL. 1967. Estructura y Hermenéutica en Claude Lévi-Strauss. En: Problemas del estructuralismo. Editorial Universitaria de Córdoba, Argentina.

SÁNCHEZ, RAFAEL. 1970. EI montaje cinematográfico, arte de movimiento. Ediciones Nueva Universidad. Universidad Católica de Chile. Editorial Pomaire.
STAM, ROBERT ET AL. 1999. Nuevos conceptos de la teoría del cine. Piados Comunicaciones 106. Ediciones Piados Ibérica. Barcelona. España.

TODOROV, TZVETAN. 1991. Categorías del relato literario. En: Análisis Estructural del Relato compilado por Roland Barthes. Premia Editora, México.

VEGA, ALICIA ET AL. 1979. Re-visión del cine chileno. Editorial Aconcagua, Colección Lautaro.

ZUNZUNEGUI, SANTOS. 1996. La Mirada cercana, microanálisis fílmico. Ed. Páidos Ibérica. España.

FILMOGRAFÍA

AYLWIN, CHRISTIAN. 2003. Yikwa ni Selk'nam (nosotros somos los Selk'nam). 16mm / 50'. O vo Films, Chile.

CASTILLO, PAOLA. 2001. La última huella. Video Digital / 65'. Errante producciones, Chile.

CHAPMAN, ANNE. 1990. Homenaje a los Yaganes: los indios de Tierra del Fuego y Cabo de Hornos. 40'. Centre National de la Recherche Scientifique, Francia.

DE AGOSTINI, ALBERTO MARÍA. 1918. Tierras Magallánicas. 35mm / 60' (Fuente Videoteca del Museo Chileno de Arte Precolombino)

DINAMARCA, HERNÁN. 2003. Estrecho de Magallanes. (Des)Encuentros de dos miradas. DVCAM / 60'. FONDART, Gobierno de Chile.

PIANA, ERNESTO LUIS. 1988 Etnoarqueología de los canales fueguinos. $27^{\prime}$.

1997. Humo en los ojos, Yámanas de Tierra del Fuego. 25'. Universidad Autónoma de Barcelona y CADIC, Arg.

PRELORAN, J ORGE, ANNE CHAPMAN, Y ANA MONTES. 1977. Los Onas, Vida y Muerte en Tierra del Fuego. $16 \mathrm{~mm} / 50$ '. Comité Argentino del Film Antropológico.

SANCHEZ, RAFAEL. 1964. Chile Paralelo 56. 16mm / 23'. Instituto Fílmico, Pontificia Universidad Católica, Chile.

SANHUEZA, IVÁN. 1992. Mankacen: el cazador de sombras. FONDART, Gobierno de Chile (no hay copias disponibles para su visualización).

SOLAR, LUIS Y J OSÉ PÉRES DE ARCE. 1985. Selknam. U-Matic / 30'. Museo Chileno de Arte Precolombino, Chile.

TORRES, CONSTANTINO. 1987. Videos J uan Downey: arte como experiencia. En Video Porque Te Ve, Ediciones Visuala Garería pp. 69-71.

URSIC, JUAN Y CARLOS VEGA. 1991. EI Valle del Secreto. TVN (Pta. Arenas) y FONDECYT No 900001, Pta. Arenas, Chile. 
ANEXO 1

TABLA 1. "La última huella" (2001/65')

\begin{tabular}{|llcc|}
\hline № & \multicolumn{1}{c}{ Nombre Secuencia } & № Planos & Duración en min. \\
\hline S01 & Presentación & 26 & 4,67 \\
S02 & Villa Ukika y hermanas Calderón & 37 & 4,73 \\
S03 & Familiares y diccionario Yagán & 40 & 8,52 \\
S04 & Recuerdo de la vida pasada & 56 & 8,94 \\
S05 & La memoria como herencia & 30 & 4,02 \\
S06 & En busca de la pintura corporal & 79 & 12,41 \\
S07 & Cestería, el arte de tejer & 54 & 7,34 \\
S08 & Visita al Cementerio & 23 & 3,43 \\
S09 & Vivienda, el antiguo hogar & 20 & 3,12 \\
S10 & La memoria fotográfica & 18 & 2,80 \\
S11 & Reflexión final & 17 & 2,13 \\
\hline & TOTAL & 400 & 62,11 \\
\hline
\end{tabular}

TABLA 2. "La última huella" (2001/65')

\begin{tabular}{|lcc|}
\hline Motivo & № de Planos & Duración en min. \\
\hline Ursula y Cristina & 59 & 13,45 \\
Paisajes & 47 & 6,10 \\
Fotos Antiguas & 38 & 5,39 \\
Cestería & 34 & 6,76 \\
Narrador Yagán & 28 & 4,69 \\
Poblado Pto. Williams & 27 & 1,88 \\
De Agostini (Película Antigua) & 23 & 2,94 \\
Viaje por Canales & 23 & 2,97 \\
Cementerio & 20 & 2,72 \\
\hline Otros & 101 & 15,20 \\
\hline
\end{tabular}

TABLA 3. "Yikwa ni Selk'nam" (2002/50)

\begin{tabular}{|c|c|c|}
\hline Descripción Secuencia & № planos & Duración en min. \\
\hline S01. Presentación y titulo & 11 & 3,24 \\
\hline S02. EI Hain (ceremonia de iniciación) & 79 & 6,23 \\
\hline S03. Mito de Origen & 90 & 7,14 \\
\hline S04. Espíritus & 16 & 0,94 \\
\hline S05. Fuego 01 (matriarcado) & 5 & 0,82 \\
\hline S06. La ceremonia & 25 & 2,33 \\
\hline S07. Los primeros antepasados & 29 & 2,99 \\
\hline S08. Fuego 02 y 03 (engaño) & 13 & 2,76 \\
\hline S09. Taita (banda de niños) & 148 & 9,84 \\
\hline S10. Fuego 04 (combate final) & 20 & 3,60 \\
\hline S11. Mito de vida eterna & 22 & 2,19 \\
\hline S12. Fuego 05 (origen del Hain) & 7 & 1,00 \\
\hline S13. Parto de Luna y final & 21 & 1,96 \\
\hline TOTAL & 486 & 45,04 \\
\hline
\end{tabular}


TABLA 4. "Yikwa ni Selk'nam (2002/50')

\begin{tabular}{|lcc|}
\hline Motivo & No de Planos & Duración en min. \\
\hline Foto & 160 & 8,66 \\
Paisaje & 95 & 10,58 \\
Subjetiva & 40 & 4,26 \\
Fuego & 34 & 7,21 \\
De Agostini & 22 & 1,56 \\
Otros & 135 & 12,76 \\
\hline TOTAL & 486 & 45,04 \\
\hline
\end{tabular}

TABLA 5. "Yikwa ni Selk'nam" (2002/50')

\begin{tabular}{|lcc|}
\hline Motivo & $\begin{array}{c}\text { No Planos } \\
\text { con Narrador }\end{array}$ & $\begin{array}{c}\text { Duración } \\
\text { con Narrador }\end{array}$ \\
\hline Foto & 31 & 1,63 \\
Paisaje & 38 & 5,44 \\
Subjetiva & 19 & 2,26 \\
Fuego & 26 & 6,29 \\
De Agostini & 3 & 0,20 \\
Otros & 53 & 4,44 \\
\hline TOTAL & 170 & 20,24 \\
\hline
\end{tabular}

TABLA 6. "Estrecho de Magallanes. (Des) Encuentro de dos miradas" (2003/60').

\begin{tabular}{|llcc|}
\hline № & Descripción Secuencia & No planos & Duración en min. \\
\hline S01 & Presentación & 4 & 2,27 \\
S02 & Prologo. Una epopeya al sur del sur & 25 & 5,43 \\
S03 & Capítulo 1. Des-Encuentro & 75 & 8,94 \\
S04 & Cap. 2. Dos miradas que no dialogan & 70 & 8,05 \\
S05 & Cap. 3. Ritos para dos miradas & 43 & 6,50 \\
S06 & Cap. 4. Dos miradas del espacio y el tiempo & 63 & 9,28 \\
S07 & Cap. 5. Progreso moderno y conservadurismo originario & 27 & 5,16 \\
S08 & Cap. 6. Destrucción de lo originario-autodestrucción moderna & 73 & 10,83 \\
S09 & Epilogo. Encuentro de miradas & 24 & 3,92 \\
\hline & TOTAL & 404 & 60,39 \\
\hline
\end{tabular}

TABLA 7. "Estrecho de Magallanes. (Des) Encuentro de dos miradas" (2003/60').

\begin{tabular}{|lcc|}
\hline Motivo & № de Planos & Duración en min. \\
\hline Subjetiva Conquistador & 70 & 8,72 \\
Paisaje & 62 & 8,37 \\
Texto Indígena & 57 & 7,46 \\
Actor Español & 35 & 6,77 \\
De Agostini & 61 & 4,98 \\
Foto & 45 & 3,93 \\
Subjetiva b/n & 24 & 2,84 \\
Texto Histórico & 10 & 7,22 \\
otros & 42 & 10,11 \\
\hline TOTAL & 406 & 60,39 \\
\hline
\end{tabular}


TABLA 8. Motivos más frecuentes según cantidad de planos.

\begin{tabular}{|lccc|}
\hline Motivo x planos & 2001. P. Castillo & 2002. C. Aylwin & 2003. H. Dinamarca \\
\hline Primera mayoría & Ursula y Cristina & Foto & Foto + Agostini \\
Segunda mayoría & Paisaje & Paisaje & Subjetiva + Conquistador \\
Tercera mayoría & Foto & Subjetiva & Paisaje \\
\hline
\end{tabular}

\section{ANEXO 2}

Inventario General de películas y videos Documentales (1964-2003)

Fondecyt $n$ ㅇ 1030029 "Los pueblos originarios en el cine ficción

y documental chileno bajo la mirada de una antropología visual".

\section{Criterio de Selección:}

10 Realizaciones audiovisuales que aborden decisivamente el tema indígena, y que tuvieran una mediana relevancia y difusión nacional.

2ํ Serán excluídas las series documentales con temática indígena, como "AI Sur del Mundo" (UC) y/o "La Tierra en que Vivimos" (TVN), y las investigaciones periodísticas audiovisuales pues su especificidad como producto televisivo, su número de producciones y su dispersión en archivos, lo convierten en tema de investigación en sí mismo, sobrepasando las posibilidades y los objetivos de la investigación Fondecyt $\mathrm{N}^{\circ} 1030029$. Tampoco fueron incluídos los documentales indígenas (realizados por los propios indígenas) ${ }^{51}$ ni los videos antropológicos 52 por considerar que trabajos recientes han abordado el tema con profundidad.

3o Por último, el criterio de disponibilidad del material audiovisual, para su visualización y análisis, configuró el siguiente listado audiovisual: ${ }^{53}$

01) Yancovic, Nieves y J orge Di Lauro. 1964. «San Pedro de Atacama". 15 minutos.

02) Flores, Carlos et al. 1971. "Nutuayin Mapu. Recuperaremos la tierra". 8 minutos.

03) Mellet, Maria Luisa. 1971."Amuhuelaimi. Ya no te iras". 11 minutos.

04) Mendoza, Ruiz y Villanova. 1986. "El trarikan macuñ". 13 minutos

05) Sapiaín, Claudio. 1987. «N guillatun: rogativa mapuche". 15 minutos.

06) Ferrari, Marcelo. 1988. «Las aguas del desierto". 20 minutos.

07) Galaz, Cristian y Rodrigo Moreno. 1988. "Camino a Usmagama". 15 minutos.

08) Marchant, Claudio y Rodrigo Moreno. 1988. "Toconao... Y el agua bajó del cielo". 10

09) Marchant, Claudio. 1988. «Palin, El J uego de Chile". 9 minutos.

10) Mora, Patricia. 1989. "Nube de lluvia". 54 minutos.

11) Rosenblat, Pablo. 1990. "Sueños del cultrun". 30 minutos.

12) Laredo, Felipe. 1990. «La Manta de J uan Carlos". 30 minutos.

13) Benavente, David. 1991. "Raíz de Chile. Mapuche, Aymara". 50 minutos.

14) Meneses, Magaly. 1992. "Nwen ngeam wüle (la fuerza del mañana)". 12 minutos

15) Sapiaín, Claudio. 1993. "En nombre del progreso". 28 minutos.

16) Laredo, Felipe y Gunvor Sorli. 1994. "Machi Eugenia". 30 minutos

17) Laredo, Felipe y Gunvor Sorli. 1994. "Palin Bollilco Mapu Meu". 30 minutos.

18) Severín, Fabiola. 1994. "H uilli Mapu". 23 minutos.

19) Iglesias, Claudia. 1997. "Fe Grande". 38 minutos.

20) Campos, Margarita. 1998. «Quinquén, tierra de refugio". 25 minutos.

21) Castillo, Paola. 2001. "La última huella". 65 minutos

22) Aylwin, Christian. 2002. «Yikwa ni selk'nam. (nosotros los selk'nam)". 50 minutos.

23) Dinamarca, Hernán. 2003. "Estrecho de Magallanes. (Des) encuentro de dos miradas". 61 minutos.

24) Moreno, Sebastián. 2003. "Aymara". 38 minutos.

25) Muñoz, Pablo. 2003. "La Manta Cacique". 11 minutos.

51 Un ejemplo es la película "Huilli Mapu" de Fabiola Severín (1994/23') que utiliza imágenes con efectos visuales para evocar la mirada subjetiva de los caciques Huilliches.

52 Para mas información ver Bajas, María Paz. 2005. "La cámara en las manos del otro". Tesis en Antropología, Universidad Academia Humanismo Cristiano.

53 La principal fuente de consulta fue el Videoteca del Museo Chileno de Arte Precolombino y los archivos personales del equipo de investigación Fondecyt. 